\title{
Formulation and Antioxidant Activity of Serum Gel of Ethyl Acetate Fraction From Musa $x$ paradisiaca L.
}

\author{
Arini Syarifah ${ }^{1, *}$ Arif Budiman ${ }^{2}$, Siti Atun Nazilah ${ }^{3}$ \\ ${ }^{1,2,3}$ Pharmacy Faculty, Universitas Muhammadiyah Purwokerto \\ *Corresponding author. Email: arinisyarifah@ump.ac.id
}

\begin{abstract}
One of the plants that had potential as a natural antioxidant was raja banana skin. The fraction of ethyl acetate of raja banana skin (Musa x paradisiaca L.) had antioxidant activity (IC50) with value $50.25 \mathrm{ppm}$. The fraction of ethyl acetate of raja banana skin will be formulated into serum gel. This study aims to determine the physical characteristics, physical stability and free radical scavenging of serum gel of ethyl acetate fraction of raja banana skin. Concentraions were used in formulation: 0.08 gram (F1); 0.16 gram (F2), 0.24 grams (F3). The raja banana skin was extracted using 96\% ethanol by maceration method then be fractionated by using ethyl acetate. Serum gel was formulated by using carbopol as a gelling agent. It was tested for physical properties and physical stability for 28 days. Free radical scavenging activity was tested by DPPH method. Vitamin c as positive control. The results showed that the value of $\mathrm{pH}$, viscosity, spreadability serum gel fraction raja banana skin fulfil requirements. Serum gel fraction of ethyl acetate was stable in 6 cycle because there is no significant change in serum gel, was seen by value of $\mathrm{pH}$, viscosity, or spreadability. The IC50 value of serum gel fraction of ethyl acetate raja banana skin respectively: 87.947 $\mu \mathrm{g} / \mathrm{ml}(\mathrm{F} 1) ; 84,297 \mu \mathrm{g} / \mathrm{ml}(\mathrm{F} 2) ; 71,257 \mu \mathrm{g} / \mathrm{ml}$ (F3). The IC50 value of positive control and negative control were 55,595 $\mu \mathrm{g} / \mathrm{ml}$; and $205,699 \mu \mathrm{g} / \mathrm{ml}$. Statistical tests using one-way ANOVA showed that the activity of free radical catching activity of the three formulas was weaker than the positive control and fraction control used. F3 was best formulation with high antioxidant activity.
\end{abstract}

Keywords: raja banana skin, serum gel, physical stability, antioxidant

\section{INTRODUCTION}

Free radicals are reactive oxygen contains one or more unpaired electrons in outer orbitals. These compounds are very damaging and can attack protein, carbohydrates, fats, and DNA continuously. Antioxidants are compounds that can counteract the negative effects of free radicals with a mechanism to donate one or more electrons to free radicals [1]. Many antioxidant compounds are found in plants, both in flowers, leaves, and fruit. Plants contain bioactive compounds such as Flavonoids, Alkaloids and Terpenoids are potential raw materials that can be used as natural antioxidants.

One of the plants that have the potential to be natural antioxidant is Raja Banana skin. Banana skin is very rarely used because the skin is only a waste. Banana skin contains many compounds that can function as natural antioxidants.

Table I. Formulation Of Serum Gel Ethyl Acetate Of Fraction Banana Skin
Flavonoid compounds in the banana skin act as antioxidants. Flavonoid compounds that act as antioxidants in banana skin are isoflavones [2]. Banana skin contains tannin, catechin, gallocatechin, and epicatechin can act as antioxidants [2]. The ethyl acetate fraction from Raja Banana skin extract had an antioxidant activity with an IC50 value of 77,068 ppm [3]

. In another research, antioxidant activity in banana skin was $73,89 \%$ and the pulp was $66,45 \%$ in concentration 0,002 ppm.

Based on the above, The fractionation of banana skin can be formulated as an antioxidant serum gel preparation. Serum gel have the advantage that it can provide a more comfortable effect and easier to spread on the surface of the skin because of its low viscosity and semi-transparent shape. Antioxidant testing used free radical scavenging method by using the DPPH (2,2-diphenyl-1-picrylhydrazyl).

\begin{tabular}{|c|c|c|c|c|c|}
\hline \multirow{2}{*}{ Material } & \multicolumn{5}{|c|}{ Concentration \% } \\
\cline { 2 - 6 } & F1 & F 2 & F3 & KN & KP \\
\hline Ethyl acetate of fraction banana skin & 0,08 & 0,16 & 0,24 & - & Vit C \\
\hline Carbopol & 1,5 & 1,5 & 1,5 & 1,5 & 1,5 \\
\hline NaOH & 0,3 & 0,3 & 0,3 & 0,3 & 0,3 \\
\hline Glycerin & 10 & 10 & 10 & 10 & 10 \\
\hline Sodium metabisulfit & 0,5 & 0,5 & 0,5 & 0,5 & 0,5 \\
\hline Methyl paraben & 0,25 & 0,25 & 0,25 & 0,25 & 0,25 \\
\hline Etanol & 3 & 3 & 3 & 3 & 3 \\
\hline Aqua deion & Ad 100 & Ad 100 & Ad 100 & Ad 100 & Ad 100 \\
\hline
\end{tabular}

$\mathrm{K} \mathrm{N}$ : Negative control group

$\mathrm{F} 1$ : formulation with a concentration of 0,08 gram of ethyl acetate fraction of banana skin

F2 : formulation with a concentration of 0.16 gram of ethyl acetate fraction of banana skin

$\mathrm{F} 3$ : formulation with a concentration of 0.24 gram of ethyl acetate fraction of banana skin 


\section{MATERIAL \& METHOD}

\subsection{Material}

Banana skin obtained from Rempoa village, Baturraden subdistrict, Purwokerto regency. The other material: vitamin $\mathrm{C}$, sodium bicarbonate, carbopol, $\mathrm{NaOH}$, glycerin, sodium metabisulfite, methylparaben, 96\% ethanol, DPPH, methanol pro analysis, rotary evaporator (IKA) and viscometer brookfield field LV.

\subsection{Method}

\subsubsection{Plant Determination}

The Banana skin was determined at the Environmental Laboratory, Faculty of Biology, Universitas Jendral Soedirman

\subsubsection{Extraction and Fractionation of banana skin}

Banana skins were washed and dried in a dryer cabinet. The dry simplisia was powdered by a blender and sieved with a 40 mesh sieve. The extraction of dried simplisia used the maceration method. 500 grams of dried simplisia was extracted with $5000 \mathrm{ml}$ of ethanol 96\%. The liquid extract obtained was concentrated using a vacuum rotary evaporator. Then, The extract was fractionated with ethyl acetate.

\subsubsection{Test for Flavonoid Content and Tannins on Ethyl Acetate of Fraction Banana Skin}

\subsubsection{Flavonoid Test}

Wilstatter test

The fraction was added 2-4 drops of concentrated $\mathrm{HCl}$ and 2-3 small pieces of $\mathrm{Mg}$ metal. Changes occur are observed from dark yellow to orange [4].

Bate-Smith test

The fraction was added with concentrated $\mathrm{HCl}$ then heated for 15 minutes over a water bath. The positive reaction if it gives a red color [5].

\subsubsection{Tannin Test}

0.1 grams of ethyl acetate fraction of Banana skin was added to $10 \mathrm{ml}$ of hot water, boiled for 5 minutes, and filtered. Part of the filtrate was added with a $1 \% \mathrm{FeCl} 3$ solution. The Positive result was shown by the formation of a blackish green color [6].

\subsubsection{Formulation of serum gel with ethyl acetate of fraction banana skin.}

The design of the formula for serum gel ethyl acetate fraction of banana skin could be seen in table 1. The carbopol was dispersed in water with a homogenizer with a used speed of $1200 \mathrm{rpm}$ and methylparaben was dissolved in ethanol. It was mixed with glycerin. Sodium metabisulfite and $\mathrm{NaOH}$ were dissolved in aquadeion respectively. It was put into the carbopol dispersion then the $\mathrm{NaOH}$ solution was added last. Furthermore, the homogenization process used homogenizer with a speed of around $1200 \mathrm{rpm}$ and increased to $1500 \mathrm{rpm}$.

\subsubsection{Evaluation of Serum Gel Ethyl acetate fraction of banana skin}

\subsubsection{Organoleptic Observations}

Organoleptic observations include observations of changes in odor, shape, color, homogeneity, and texture.

\subsubsection{Measurement of $p H$}

The $\mathrm{pH}$ test of the formula was carried out using a $\mathrm{pH}$ stick. This is done by dipping the $\mathrm{pH}$ stick into the preparation.

\section{$\underline{\text { 2.2.5.3 Viscosity Measurement }}$}

Viscosity measurements were carried out with viscometer brookfield LV on spindle 64 with use a rotation speed of 50 rpm.

\subsubsection{Spreadability Test}

0.5 grams of serum gel is placed on a round glass, then covered with another glass that has been weighed. Left for 1 minute then measured the diameter of the spread, after 1 minute added a load of 50 grams. Left for 1 minute then measured again the diameter of the spread.

\subsubsection{Cycling Test Method}

The serum gel was stored at $4^{0} \mathrm{C}$ for 24 hours, then transferred to an oven at $40 \pm 2{ }^{\circ} \mathrm{C}$ for 24 hours (one cycle). The test was carried out in 6 cycles and then carried out organoleptic observations (changes in color, odor, and homogeneity [6].

\subsubsection{Antioxidant Activity Test}

\subsubsection{Determination of Wavelength}

0.01 gram of DPPH was dissolved in $250 \mathrm{ml}$ of methanol (0.004\%). $1 \mathrm{ml} 0.004 \%$ DPPH solution added with $4 \mathrm{ml}$ methanol, shake until homogeneous and measured absorption in the wavelength range 400-800 $\mathrm{nm}$ [7].

\subsubsection{Determination of the Operating Time for DPPH}

\section{Solution}

$1 \mathrm{ml}$ of $0.004 \%$ DPPH solution added with $4 \mathrm{ml}$ of methanol. Then it was shaken then the absorption observed at minutes $5,10,15,20,25,30$. It could determine the operating time. 


\subsubsection{Blank Solution}

$1 \mathrm{ml}$ of $0.004 \%$ DPPH solution is added to $10 \mathrm{ml}$ of methanol then homogenized by shaking.

\subsubsection{Preparation of banana skin fraction concentration $\underline{\text { series }}$}

The ethyl acetate fraction of banana skin was weighed as much as 0.1 gram then dissolved in 100 methanol. The ethyl acetate fraction of plantain peel was made into a concentration series of $25,50,75,100$, and $125 \mathrm{ppm}$.

\subsubsection{Preparation of a serum gel test solution concentration series}

0.01 gram of each serum gel formula reconstituted with $10 \mathrm{ml}$ of methanol. Concentration series were made 25, 50, 75,100 , and $125 \mathrm{ppm}$.

\subsubsection{The antioxidant activity test of the ethyl acetate fraction of banana skin.}

Antioxidant activity testing was carried out on all concentration series, both fractions, preparations, and vitamin $\mathrm{C}$ (positive control) that had been prepared. $2 \mathrm{ml}$ sample added $2 \mathrm{ml}$ of DPPH solution $0.004 \%$ then read at a wavelength of maximum absorbance. The percentage of inhibition of the ethyl acetate fraction of banana skin was calculated against DPPH free radicals.

Antioxidant activity can be determined by the following equation:

$$
\% \text { Inhibition }=\frac{\text { A DPPH }- \text { A Test Solution }}{\text { A DPPH }} x 100
$$

$\%$ inhibition $=$ percentage inhibition of antioxidants

A control $=$ absorbance of DPPH

A Test Solution $=$ absorbance of the test solution

\section{$\underline{\text { 2.2.7.7 IC50 measurement }}$}

Furthermore, the data obtained are processed use a linear equation of the form $y=b x+a$ between the concentration of the serum gel test solution $(\mathrm{x})$ and the percentage of free radical scavenger activity (y). This linear regression equation is used to determine concentration of the serum gel test solution and vitamin C could inhibit $50 \%$ of the absorbance of the DPPH.

\subsubsection{Results Analysis}

Organoleptic, homogeneity,spreadability and $\mathrm{pH}$ values were analyzed by descriptive. Meanwhile, the results of the viscosity test, stability test, and $\mathrm{IC}_{50}$ were analyzed using the One Way Variant Analysis (ANOVA) method with a confidence level of $95 \%$. Free radical scavenging activity data of serum gel were calculated with an $\mathrm{IC}_{50}$ value and analyzed by a one way ANOVA test with a confidence level of $95 \%$.

\section{RESULT \& DISCUSSION}

\subsubsection{Plant Determination}

The results of plant determination indicated that the plants used in this research were raja banana skin ( Musa x paradisiaca $\mathrm{L}$.) from the Musaceae family .

\subsubsection{Extraction and Fractionation of banana skin}

The extraction of banana skin was carried out using the maceration method. It was because the process does not use heat so that it can keep the thermolabile components like flavonoids [9]. In this method, ethanol $96 \%$ was used as a solvent to extract flavonoids and tannins. Ethanol has been known as a good solvent for polyphenol extraction such as flavonoid and safe for human consumption [10].

The viscous extract obtained from the extraction of banana skin was 72.29 grams and the randemen value was $14.458 \%$. The extract obtained is brownish yellow, thick, and had a distinctive smell of banana skin. The next process was fractionation. The ethyl acetate fraction of thick banana skin obtained was 6.4 grams and the randemen value was $12.8 \%$. From these results, it could be concluded that the randemen value in the process extraction and fractionation was small. The reason for small randemen value was carried out in stages fractionation and extraction so that many active compounds had been found in the previous solvent.

\subsubsection{Identification of Flavonoids and Tannins in Ethyl Acetat of Fraction of Banana Skin}

\subsubsection{Flavonoid Test}

Wilstatter Test

The results obtained were that the ethyl acetate fraction of plantain fruit peels changed color from yellow to reddish-orange (fig 1). These changes color indicate that the skin of the banana contains flavonoids. The addition of $\mathrm{HCl}$ in the wilstatter test aims to hydrolyze flavonoid to flavonoid aglycones by hydrolyzing o-glycosyls. This hydrolyzed glycosyl will be replaced with $\mathrm{H}+$ atoms from acids which have strong electronegativity properties. $\mathrm{Mg}$ powder was added in the solution produces a complex compound. It was marked by color change become red color. This magnesium ion will bind to the flavonoid compounds present in the fraction so that a red solution appears [9].

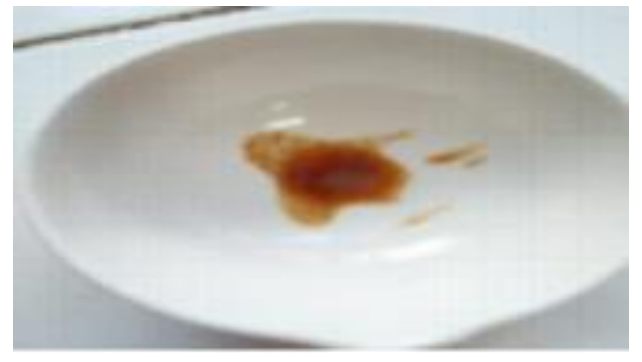

Figure 1 Wilstatter Test Result 


\section{Bate-Smith test}

In the bate smith test, ethyl acetate fraction of banana skin showed positive results because there was a dark red color occurs (Figure 2.). These changes color indicate that the skin of banana contains flavonoids.

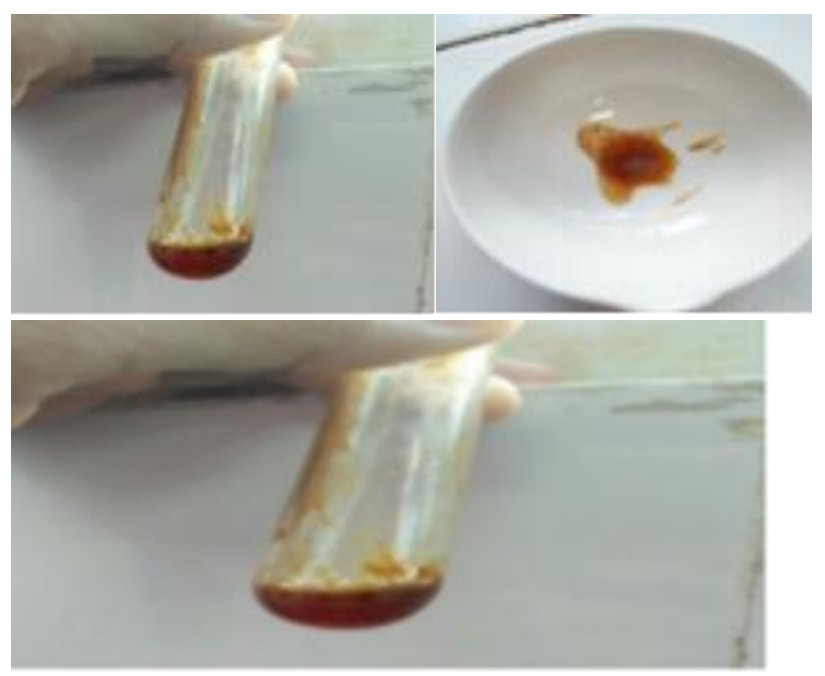

Figure 2 Bate-Smith Test Result

\subsubsection{Tannin Test}

Ethyl acetate fraction showed positive results in this test because there was a blackish green color change when the addition of $\mathrm{FeCl} 3$. Mechanism change of color is tannins react with $\mathrm{Fe} 3+$ ions to form complex compounds [11].

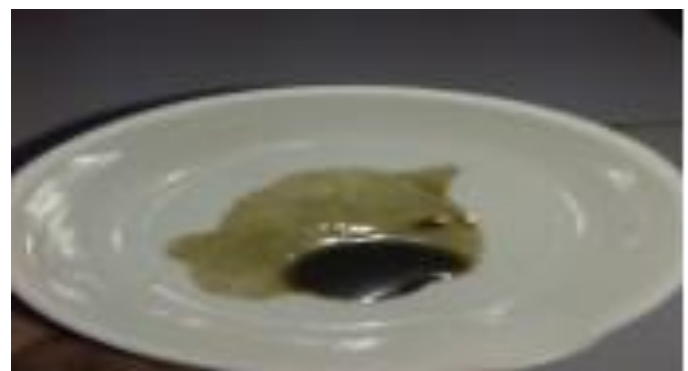

Figure 3 Tannin Test Result

\subsubsection{Formulation of serum gel with ethyl acetate of fraction banana skin.}

Formulation of Serum Gel Formulation with Ethyl Acetate Fraction of Banana skins. The result of formula serum gel with ethyl acetate fraction shows Figure 4.

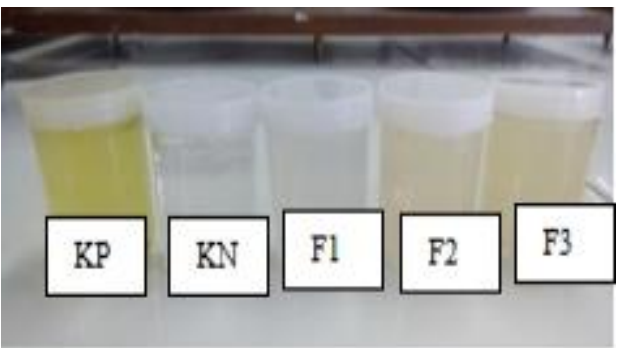

Figure 4 Formula KP, KN, F1, F2 and F3.

\subsubsection{Physical Test of Serum Gel Ethyl Acetate} Fraction of Banana Skin.

\subsubsection{Organoleptic}

The Organoleptic examination was carried out by a descriptive method. Organoleptic results show in table 2.

Table 2 Organoleptic test serum gel of fraction banana skin result

\begin{tabular}{|c|c|c|c|c|c|}
\hline \multirow{2}{*}{ Formula } & \multicolumn{5}{|c|}{ Result } \\
\cline { 2 - 6 } & Color & Odor & Shape & $\begin{array}{c}\text { Spreadability } \\
(\boldsymbol{c m})\end{array}$ & Homogenity \\
\hline F1 & $\begin{array}{c}\text { Cloudy } \\
\text { White }\end{array}$ & $\begin{array}{c}\text { Spesific } \\
\text { Banana } \\
\text { Odor }\end{array}$ & Semisolid & $6,6 \pm 0,1$ & Homogen \\
\hline F2 & Cream & $\begin{array}{c}\text { Spesific } \\
\text { Banana } \\
\text { Odor }\end{array}$ & Semisolid & $6,6 \pm 0,635$ & Homogen \\
\hline KN & Brown & $\begin{array}{c}\text { Spesific } \\
\text { Banana } \\
\text { Odor }\end{array}$ & Semisolid & $5,9 \pm 0,152$ & Homogen \\
\hline & $\begin{array}{c}\text { Spesific } \\
\text { Carbopol } \\
\text { Odor }\end{array}$ & Semisolid & $6,8 \pm 0,152$ & Homogen \\
\hline
\end{tabular}

Serum gel without ethyl acetate fraction (negative control) had clear color. The variation in the concentration of the ethyl acetate fraction of banana skin in formula did not affect the odor of the serum gel formula. The serum gel formula had a specific banana odor. All serum gels were made had a soft texture, spread easily, semisolid consistency, and do not feel sticky. The values of spreadability indicate that the gel is easily spreadable by small amount of shear [12].

The homogeneity test results showed that the serum gel formula did not feel rough or lumpy when touched, and there were no small powders so it could be said to be physically homogeneous. This indicates that the difference in the concentration of the ethyl acetate fraction of banana skin does not effect the homogeneity of serum gel.

\subsubsection{2 pH of Serum Gel}

PH measurement results are shown in Table 3 . The ideal $\mathrm{pH}$ value of the preparation in accordance with the $\mathrm{pH}$ of the skin is 4.5-7 (SNI 16-4399-1996). If the formulation too acidic, it will cause skin irritation. If the preparation too alkaline, it will cause dry and scaly skin [13]. Based on the results of $\mathrm{pH}$ measurements, it is known that the serum gel ethyl acetate fraction of banana skins have a $\mathrm{pH}$ that matches the requirements of topical preparations. 
Table 3 Results Serum Gel pH Measurement

\begin{tabular}{|c|c|}
\hline Formula & $\mathbf{p H}$ mean $\pm \mathbf{S D}$ \\
\hline F1 & $4.5 \pm 0$ \\
\hline F2 & $5 \pm 0$ \\
\hline F3 & $5 \pm 0$ \\
\hline K N & $5 \pm 0$ \\
\hline
\end{tabular}

\subsubsection{Serum Gel Viscosity Measurement}

The aim of measuring the viscosity of serum gel is to determine the viscosity value of a formula. The results of the viscosity measurements average serum gel formula shows in Table 4.

Table 4 Results Serum Gel Viscosity

\begin{tabular}{|c|c|}
\hline Formula & Mean viscosity (cps) \pm SD \\
\hline F1 & $12230 \pm 199.7498$ \\
\hline F2 & $13630 \pm 635.9245$ \\
\hline F3 & $15730 \pm 425.6759$ \\
\hline K N & $11340 \pm 443.9595$ \\
\hline
\end{tabular}

The viscosity value of gel serum according to SNI $16-4399-1996$ is in the range $2000-40000 \mathrm{cP}$. Based on the measurement results, the four serum gel ethyl acetate fraction of banana skin had a viscosity between 11340 to $15730 \mathrm{cps}$. So it can be concluded that the viscosity gel serum is qualifying into the viscosity range.

The difference in the concentration of the ethyl acetate fraction of banana skins was different $(p<0.05)$. The higher concentration of the fraction added makes the greater the viscosity.

\subsubsection{Stability Testing Of Serum Gel With Cycling Test Method}

Cycling Test method aims to test the stability of serum gel formula and is carried out for 12 days or as many as 6 cycles. The Cycling Test result method can be see in table 5 .

Based on the table 5, formulations 1, 2, 3 and $\mathrm{KN}$ showed no color change after the 6 th cycle. This indicates that the serum serum gel formula stable. Formula remains from the beginning of the cycle to the 6th cycle. However, in positive control, there was a change when the 6th cycle, was initially light yellow to dark yellow and has low value viscosity (table VI). This is because in the positive control contain vitamin $\mathrm{C}$ can cause oxidized process in the presence of oxygen. It is make viscosity decrese [14].

The $\mathrm{pH}$ of the serum gel was examined at the beginning and end of the cycle. According to SNI No.164399-1996, the range of $\mathrm{pH}$ values before and after the cycling test was still within safe limits for topical preparations. Based on the table above, the formulations 1,2, 3 and negative controls did not change the $\mathrm{pH}$ (table 6). This results shows that the serum gel formula was stable.

Table 5 Results Of Organoleptic Stability Testing Of Serum Gel Using The Cycling Test Method

\begin{tabular}{|c|c|c|c|c|}
\hline \multirow{3}{*}{ Formula } & \multicolumn{4}{|c|}{ Observation } \\
\hline & \multicolumn{2}{|c|}{ Color } & \multicolumn{2}{|c|}{ Shape } \\
\hline & $\begin{array}{c}\text { The start of } \\
\text { the cycle }\end{array}$ & Cycle-6 & $\begin{array}{c}\text { The start of the } \\
\text { cycle }\end{array}$ & Cycle-6 \\
\hline F1 & White cloudy & White cloudy & Semi solid & Semi solid \\
\hline $\mathrm{F} 2$ & Cream & Cream & Semi solid & Semi solid \\
\hline F3 & Light brown & Light brown & Semi solid & Semi solid \\
\hline $\mathrm{KN}$ & Clear & Clear & Semisolid & Semisolid \\
\hline $\mathrm{KP}$ & Light yellow & Dark yellow & Semisolid & Liquid \\
\hline
\end{tabular}

Table 6. The results of testing the stability of $\mathrm{pH}$ and viscosity of serum gel using the Cycling Test method

\begin{tabular}{|c|c|c|c|c|}
\hline \multirow{3}{*}{ Formula } & \multicolumn{4}{|c|}{$\overline{\text { Observation }}$} \\
\hline & \multicolumn{2}{|c|}{ pH } & \multicolumn{2}{|c|}{ Viscosity } \\
\hline & $\begin{array}{c}\text { The start of } \\
\text { the cycle }\end{array}$ & Cycle-6 & $\begin{array}{l}\text { The start of } \\
\text { the cycle }\end{array}$ & Cycle-6 \\
\hline F1 & 4.5 & 4.5 & 12330 & 11880 \\
\hline $\mathrm{F} 2$ & 5 & 5 & 13530 & 11220 \\
\hline F3 & 5 & 5 & 15270 & 13470 \\
\hline $\mathrm{KN}$ & 6 & 6 & 10830 & 8520 \\
\hline KP & 6 & 7 & 9870 & 6060 \\
\hline
\end{tabular}

\subsubsection{Antioxidant activity test of serum gel formula.}

\subsubsection{Result of Determination of Maximum Wavelength $\underline{(\lambda \max ) \text { of } D P P H}$}

The measurement results show that the maximum DPPH $0.1 \mathrm{mM}$ wavelength was $517 \mathrm{~nm}$ with an absorbance of 0.899 .

\subsubsection{Antioxidant Activity of the Ethyl Acetate Fraction of Banana Skin.}

The DPPH method measures the ability of a compound to scavenge free radicals. The ability of antioxidants is related to the ability of compound components to donate electrons or hydrogen. Any molecule can donate electrons or hydrogen will react to DPPH. This mechanism will change the color of the solution, from purple to yellow [15].

Antioxidant activity is the ability of a compound or an extract to inhibit oxidation reactions which can be expressed by the presentation of DPPH absorption. The value of IC50 is obtained from the relationship between percent inhibition and concentration [16]. Table VII shows category antioxidant 
activity according to IC50 value. Table 7 shows the result of antioxidant activity FI, F2, F3, KN and KP.

Table 7. Category Antioxidant Activity

\begin{tabular}{|c|c|}
\hline IC50 Value (ppm) & Category Antioxidant Activity \\
\hline$<50$ & Very strong \\
\hline $50-100$ & Strong \\
\hline $100-150$ & Moderate \\
\hline $150-200$ & Weak \\
\hline
\end{tabular}

Table 8. The result of antioxidant Activity

\begin{tabular}{|c|c|}
\hline Formulations & Average IC 50 $(\mathbf{p p m}) \pm$ SD \\
\hline F1 & $87.947 \pm 0.962$ \\
\hline F2 & $84.297 \pm 1.165$ \\
\hline F3 & $71.257 \pm 1.139$ \\
\hline K N & $205,699 \pm 2,455$ \\
\hline KP & $55.595 \pm 1,727$ \\
\hline
\end{tabular}

From these results, it can be concluded that a serum gel of F1, F2, and F3 had strong antioxidant activity. Gel serum with various concentrations had higher antioxidant activity when compared with the negative control group. One-way ANOVA statistical test shows that the IC50 value of the three formulas had a significant difference $(p<0.05)$ compared with the negative control. This means that the serum gel formula has antioxidant activity. The three formulas when compared with positive control show significant differences $(p<0.05)$. The serum gel of the ethyl acetate fraction of banana skins at all concentrations had less antioxidant activity than the positive control group. This was estimated because of the inadequate release of active substances from the base when reacting with DPPH. Other factors such as environmental factors like light which can cause an oxidation process which results in a decrease in the antioxidant activity of the preparation [17]

\section{CONCLUSION}

The ethyl acetate fraction of banana skin can be formulated in serum gel and have a good value in physical propertis, spreadability, $\mathrm{pH}$, and viscosity. The serum gel is stable to the cycling test and F3 is a formula that has great antioxidant value.

\section{REFERENCES}

[1] Sayuti, K and Yenrina, R, Antioksidan Alami dan Sintetik, 2015, Padang: Andalas University Press.

[2] Rohmiyati, Septina, Uji Aktivitas Antioksidan Fraksi Etil Asetat Ekstrak Etanol Kulit Pisang Raja (Musa paradisiaca var. Raja) dengan Metode DPPH (1,1difenil-2-pikrilhidrasil) Beserta Identifikasi Senyawa Flavonoid, thesis, 2016, Universitas Wahid Hasyim.

[3] Someya, S.Y. Yoshiki and K. Okubo., Antioxidant compounds from banana (Musa cavendish), Food Chemistry, 2002, pp. 351-354, DOI : doi.org/10.1016/S0308-8146(02)00186-3
[4] Achmad, S.A, Kimia Organik Bahan Alam, 1986, Jakarta: Karnunika.

[5] Nugrahani R, Yayuk A dan Aliefman H. Skrining Fitokimia dari Ekstrak Buah Buncis Dalam Sediaan Serbuk. Proceding Kimia, $\quad$ pp 36-42. DOI: https://doi.org/10.29303/jppipa.v2i1.38

[6] Ebennezer, E, Uji Stabilitas Fisik dan Pengaruh Vitamin C terhadap Aktivitas dan Daya Penetrasi Ekstrak Etanol Kulit Manggis (Garcinia mangostanta L.) pada Serum Antikerut, 2015,thesis, Universitas Indonesia.

[7] Lachman, L., Lieberman, H.A., dan Kanig, J, The Theory and practice of industrial pharmacy 3rd Edition. India: Vargheseng Publishing hous, 1986, pp: 1091-1095.

[8] Izzati, N.N., Diniatik., Rahayu W.S, Aktivitas Antioksidan Ekstrak Perasan Daun Manggis (Garcinia mangostana L.) Berdasarkan Metode DPPH (2,2 Diphenyl-1-phycryl hydrazil), Pharmacy, 2012, pp 111-120, DOI: 10.30595/pji.v9i3.762

[9] Budiarti, A., Ulfah, M. dan Oktania, F.A, Aktivitas Antioksidan Fraksi Kloroform Ekstrak Etanol Daun Sirsak (Annona muricata L.) dan Identifikasi Kandungan Senyawa,2014, thesis, Pharmacy faculty, Universitas Wahid Hasyim, pp.1-6.

[10] Do,Quy Diem., Angkawijaya, Artik Elisa., Tran-Nguyen, Phuong Lan., et al, Effect of extraction solvent on total phenol content, total flavonoid content, and antioxidant activity of Limnophila aromatica, journal of food and drug analysis,2014,pp. 296-302, DOI doi.org/10.1016/j.jfda.2013.11.001

[11] Marliana S.D., Venty S dan Suyono, Skrining Fitokimia dan Analisis Kromatografi Lapis Tipis Komponen Kimia Buah Labu Siam (Sechium edule Jacq. Swartz) Dalam Ekstrak Etanol, thesis, 2005, Science Faculty, Universitas Sebelas Maret.

[12] Singh, Vijay Kumar., Singh, Praveen Kumar., Sharma, Purnendu Kumar., et al, Formulation And Evaluation Of Topical Gel Of Acelofenac Containing Piparine, pp 5266-5279

[13] Harborne, J.B, Phytochemical Method, 1987, Newyork: Chapman and Hall.

[14] Gozali, Formulasi Krim Pelembab Wajah yang Menggunakan Tabir Surya Nanopartikel Zink Oksida Salut Silikon, Farmaka, 2005, pp. 37-47.

[15] Health Ministry Of Republic Indonesia, Farmakope Indonesia, Edisi IV, 1995, Jakarta: Departemen Kesehatan Republik Indonesia.

[16] Nihlati, A.I., Abdul, R., dan Triana, H, Daya Aktivitas Rimpang Temu Kunci (Boesenbergia pandurate (Roxb.) Schlecth) dengan Metode Penangkapan Radikal Bebas DPPH, 2011, Yogyakarta: UGM Press.

[17] Andarwulan, N., Wijaya, H., Cahyono, D.T, Aktivitas Antioksidan dari Daun Sirih (Piper betle L.)". Teknologi dan Industri Pangan, 1996, pp.29-30.

[18] Muawwanah, Isolasi, Uji Aktivitas Antioksidan dan Toksisitas Fraksi Polisakarida dari Alga Merah (Glacilaria verrucosa), 2015,Thesis, Science Faculty, Universitas Hasanudin

[19] Noviana, W,S, Uji aktivitas antioksidan dari ekstrak bekatul padiketan merah dan hitam(oryza sativa L. Var. Glutinosa) dan formulasinya dalam sediaan krim. Pharmacy, 2016, pp.101116. 